\title{
Female prison system: a case study of public security policies
}

\author{
BRUNA RIOS MARTINS SANTOS ${ }^{1}$ \\ VÂNIA APARECIDA REZENDE ${ }^{2}$
}

\author{
${ }^{1}$ Universidade Federal de SÃo JoÃo del-ReI (UFSJ), SÃo JoÃo dEL- REI - MG, BRAZIL \\ ${ }^{2}$ UnIVERSIDAde Federal de SÃo JoÃo deL-REI (UFSJ) / DePARTAMENTO dE CIÊNCIAS AdMINISTRATIVAS E CONTÁbEIS, SÃo JOÃO DEL-REI - MG, BRAZIL
}

\begin{abstract}
Although the rate of female incarceration has increased significantly in recent years, building public policies that encompass the gender perspective is still a state process to be consolidated in the government agenda. This article presents a case study that investigates the female prisoner universe of a region in the state of Minas Gerais. The objective was to analyze how gender differences influence the construction of public security policies in the prison system, and affects the experiences of female prisoners. This qualitative research used semi-structured interviews and documentary analysis, the data produced were submitted to content analysis proposed by Bardin, whose textual categorization occurred by classifying constituent elements of a set and regrouping from the common characteristics of these elements. From this analysis, four categories were constructed: imprisonment and gender; maternity and prison; public policies; and prison life. The main results indicate that gender differences in the elaboration of policies related to the prison system influence the experiences of incarcerated women, particularly regarding motherhood. Although significant advances were made to adequate public policies to the specificities of female prisoners, this is still a recent and incipient issue.
\end{abstract}

Keywords: Public policy. Public security. Female prision. Gender.

\section{Sistema carcerário feminino: uma análise das políticas públicas de segurança com base em um estudo local Resumo}

Embora a taxa de encarceramento feminino tenha aumentado significativamente nos últimos anos, a construção de políticas públicas que englobam a perspectiva de gênero ainda é um processo estatal a ser consolidado na agenda governamental. Este trabalho apresenta o estudo de um caso que teve como locus de investigação o universo carcerário feminino de uma comarca no estado de Minas Gerais, seu objetivo foi analisar como a diferença de gênero, na construção de políticas públicas de segurança no sistema prisional, influencia as vivências do feminino no cárcere. A pesquisa, de natureza qualitativa, utilizou entrevistas com roteiros semiestruturados e análise documental. Os dados produzidos foram submetidos à análise de conteúdo proposta por Bardin, cuja categorização textual ocorreu pela classificação de elementos constitutivos de um conjunto e reagrupamento com base em características comuns destes elementos. Por meio desta análise, foram construídas quatro categorias: encarceramento e gênero; maternidade e cárcere; políticas públicas e vivências no cárcere. Os principais resultados apontam que as especificidades de gênero no encarceramento feminino influenciam as vivências produzidas resultantes de vários tipos de violência que marcam definitivamente a vida das mulheres, destacando-se a relação com a maternidade, apontada como a principal fonte de sofrimento. Apesar de avanços significativos, a inserção da questão de gênero na formulação das políticas públicas de segurança pública ainda é recente e incipiente no que tange às especificidades do cárcere feminino.

Palavras-chave: Políticas Públicas. Segurança Pública. Cárcere Feminino. Gênero.

\section{Sistema carcelario femenino: un análisis de las políticas públicas de seguridad a partir de un estudio local}

\section{Resumen}

Aunque la tasa de encarcelamiento femenino haya aumentado significativamente en los últimos años, la construcción de políticas públicas que engloban la perspectiva de género sigue siendo un proceso estatal a consolidarse en la agenda gubernamental. Este trabajo presenta el estudio de un caso que tuvo como locus de investigación el universo carcelario femenino de una comarca del estado de Minas Gerais, su objetivo fue analizar cómo la diferencia de género, en la construcción de políticas públicas de seguridad en el sistema penitenciario, influye en las vivencias de lo femenino en la cárcel. La investigación, de naturaleza cualitativa, utilizó entrevistas con guiones semiestructurados y análisis documental. Los datos producidos se sometieron al análisis de contenido propuesto por Bardin, y su categorización textual se llevó a cabo por la clasificación de elementos constitutivos de un conjunto y reagrupamiento a partir de las características comunes de estos elementos. Por medio de este análisis se construyeron cuatro categorías: encarcelamiento y género; maternidad y cárcel; políticas públicas y vivencias en la cárcel. Los principales resultados apuntan que las especificidades de género en el encarcelamiento femenino influencian las vivencias producidas resultantes de varios tipos de violencia que marcan definitivamente la vida de las mujeres, especialmente, la relación con la maternidad, indicada como la principal fuente de sufrimiento. A pesar de los avances significativos, la inserción de la cuestión de género en la formulación de políticas públicas de seguridad pública todavía es reciente e incipiente en lo que se refiere a las especificidades de la cárcel femenina.

Palabras clave: Políticas públicas. Seguridad pública. Cárcel feminina. Género. 


\section{INTRODUCTION}

Female imprisonment in Brazil has increased significantly in the last years, this reality affects both public security policies and specific policies that aim to fight gender inequality. Although women are the minority in the world of crime, the rate of female imprisonment has escalated dramatically in this country. The female prison population increased $656 \%$ between 2000 and 2016, reaching 42.355 women imprisoned, while the male prison population increased $293 \%$ in the same period. In what concerns the rate of female incarceration per 100 thousand inhabitants, Brazil stands in the third place, only behind USA and Thailand (BRASIL, 2017A; FBSP, 2018).

The growth of this incarcerated population arouses the need of discussing gender issues. The inclusion of this issue in the Brazilian government's agenda happened because of the intervention of feminist movements and the influence of international organizations (FARAH, DINIZ, MARCONDES et al., 2018). However, the available treatment provided for imprisoned women in prision is almost the same as the one provided for men, disregarding specific features - there's an indifferent treatment that makes the rehabilitation process for convicted women even more difficult (FRANÇA, 2014)

It is of great significance approaching the gender issue as a way of promoting the setting-up of public policies that consider the status of female imprisonment. However, this is a field in which the disagreement is the main characteristic present in the trial of reaching a conceptual definition and the modus operandi expressed in specific public policies projects (FONSECA, 2016). The reality of female prisons and the punishment of incarcerated women is a turning point to think about the need of state actions; besides the deprivation of liberty, women face precarious conditions in the prisons. Prisons are places that were not built taking into consideration gender specificities, in which the penalty rules and their execution were structured by a male perspective, disregarding female needs (BORGES, 2001; ARTUR, 2009).

The (de)construction of a gender concept runs through history, since it is a result of the feminist movement action; on the other side, it is possible to say that it is a socially built concept. Along this social and cultural (re)construction, specific abilities and spaces are assigned, taking into consideration the priorities of each gender. The dissemination of the term shows the polyphony and richness present in this arena of debate, constituting a definite ground for epistemological construction (MATOS, 2008; MUXÍ, 2014; MOTTA, 2017).

The security public policies are of interdisciplinary nature, in this way, its institutionalization demands diverse actions. In this sense, the construct "experiences" explored in this piece of research finds resonance in many fields of knowledge. According to Uziel and Scisleski (2018), the prison system and public security have been influenced by psychological forays, in a way of opposing the punitive logic. Thus, the authors are unsettled by the practices in the prison system that yield ways of killing the "impossible to live/invisible existences". Besides this, the contribution of contemporary sociology while analyzing the policies is taken into consideration. According to Cortes and Lima (2012), the contemporary sociology observes the social identities and the constitution of social groups that may demand or be the subject of public policies. In what concerns "experiences", this paper takes the concept that what has been lived with significant intensity completely changes the general context of one's existence. In this manner, the experience must be relevant enough to affect decisively the life of the person who experiences it, being impossible to rationally determine its content (VIESENTEINER, 2013)

The purpose of this paper is in line with Farah, Diniz, Marcondes et al. (2018) when they point out that the beginning of the restructuring of gender public policies happened with the inclusion of the gender issue in the Brazilian government's agenda, which occurred as a response for the action of feminist movements and under the influence of international organizations. In other study, Farah (2004) identified that the gender field of study took root in Brazil in the end of the 70's, together with the strengthening of the feminist movement in the country. In this way, it is possible to say that the ideas hereby presented find resonance in a broad field. This study, while working with local empiric evidence, comes out as an opportunity to broaden the relational debate between gender and public policies.

From this contextualization, this paper aims to analyze how the gender difference in the building of security public policies in the prison system affects the female experiences in prision. This paper had as the locus for investigation the female prison universe in a district in the state of Minas Gerais. This piece of research, besides its introduction, pursued to contextualize public policies in the Brazilian scenario as well as the gender issue. After this, the methodological path was referenced and finally the results analysis and the final considerations were presented. 


\section{Security Public Policies and the Brazilian Context}

The Public Policy, as a field of study and academic subject, was born in the USA as a subarea of Political Sciences and its studies were regulated by the assumption that, in stable democracies, the government actions can be scientifically formulated and analyzed by researchers. Because of the complexity and the lack of agreement about the concept, in a broad manner, the development of public policies is related to the needs of solving issues in order to promote the common welfare. Critically, it is claimed that these definitions do not take into consideration the struggle among thoughts and interests that should be the essence of politics. However, the instrumentalized public policy can take on different values in its standards according to the level in which the State provides goods and services (SOUZA, 2003; BREUS, 2006; SARAVIA, 2006; SOUZA, 2006; LIMA, 2011).

Brazil has undergone a series of reforms in the last decades. Under the influence of the changes in the international scenario in the 50's and 60's, it is possible to notice that new ways of management and planning were implemented in Brazil. From the 70's and 80's a new scenario towards redemocratization emerged, culminating with the establishment of a Constituent Assembly and the promulgation of the new Constitution of 1988. This document was responsible for the broadening of social rights, ensured by public policies.

The security public policies can be defined as the ones responsible for preserving or reestablishing the social coexistence and allowing, according to Silva $(2009$, p. 635) "[...] people to enjoy their rights and do their activities without being disturbed by other people, except when these other people are claiming their own rights or defending their legitimate interests". According to Filocre (2009), the security public policy becomes a public policy if it constitutes simultaneously a proposal for social life organization and actions aiming to achieve a specific goal of public interest. In the Brazilian context, Adorno (2002) postulates that, since the middle of the 70's, the feeling of fear and insecurity has escalated in Brazil as a result of the official criminality rates that showed an accelerated growth of all criminal categories.

The promulgation of the Constitution in 1988 broadened the democratic perspective, introducing new approaches to subjects such as social rights, fundamental rights and respect for human dignity. The Constitution, in section 144, appoints that: "[...] Public security, the duty of the State and the right and responsibility of all, is exercised to preserve public order and the safety of persons and property" (BRASIL, 1988). The new Constitution defined the rules of the political game and the limits of legality, allowing citizens to request actions from the government (BREUS, 2006; LIMA, 2011).

The Brazilian redemocratization process and the social pressure set a change in the security public policies, broadening the discussion about the need for structural reforms. As stated by Carvalho and Silva (2011), although the Constitution of 1988 establishes a commitment to the individual and collective safety, inconsistent remedial measures applied to emergency circumstances, far from social reality, were proposed. This period incorporated new social actors in the public policies cycle. Social movements, non-governmental organizations and research centers aiming to develop practices and strategies to control public violence and help to implement these measures in the security public policies have multiplied in Brazil (ZACCHI, 2002). Public security must be understood as an articulated process characterized by institutional and social interdependence.

The initiatives in the public safety area have been constantly changing in the last decades because of the introduction of new paradigms that might be analyzed through three categories: "[...] the paradigm of national safety, present in the military regime; the paradigm of public safety, that starts with the Constitution of 1988 and the paradigm of citizen safety that starts around 2000" (FREIRE, 2009).

The Violence Atlas (IPEA and FBSP, 2018) addresses the idea of public safety administration, showing a diffusion in responsibility among many social actors and institutions. A plurality of interests, sometimes in conflict, must be managed, what emphasizes the constitutional idea that states that security is a responsibility of all people.

The security area demands an intergovernmental and intersectional articulation through specific programs aiming at decentralization and grounded in preventive actions with social participation. The measures aiming to decrease violence and criminality can be focused on three categories: through closer approximation with the population; through intense disclosure of information; and through investigation and intelligence improvement (SOUZA, MARCHIORI, OLIVEIRA et al., 2009; SCHABBACH, 2014; LIMA, BUENO and MINGARDI, 2016). However, according to what was published by the Brazilian Public Security Forum, in 2018 , there was an increase of $2.9 \%$ in the number of intentional violent deaths between 2016 and 
2017. In what concerns the prison system, according to the publication, there were 729.551 people imprisoned in 2016. An important issue to be pointed out is that the Brazilian prison system has 368.049 vacancies, that is, there are two people occupying one vacancy (FBSP, 2018).

Intending to intervene in the critical aspects identified concerning public security, some measures have been implemented in the last decades. The National Public Security Council (CONASP) was formed with the Constitution of 1988. Nowadays this council works as a three-way model, composed by representatives of civil society, government members and public security workers. This entity sought to promote technical cooperation among the federal entities on the fight against criminality. This entity is directly subordinated to the Justice Ministry, that was split apart because of the creation of the Public Security Ministry, in February 2018, according to the Provisory Act number 821. This measure is in line with the idea of a Unified Public Security System (SUSP), also approved by the National Congress.

There are previous milestones that should be pointed out, such as the creation of the Public Security Secretary (SENASP) in 1997, the building of the I National Public Security Plan and the National Public Security Fund (FNSP), in 2000, and the creation of the National Public Security with Citizenship Program (PRONASCI) in 2007 (BRASIL, 2000; SCHABBACH, 2014). In 2017, intending to fight the high rates of violence, a new National Public Security Plan was launched, having as main goals: reducing knavish homicide, feminicide and violence against women; promoting an integrated combat against organized crime and rationalizing and modernizing the prison system (BRASIL, 2017b).

The establishment of the National Work Policy inside the Prison System (PNAT), through Decree number 9.450/2018 was also very important. It aimed at increasing and qualifying job offers, entrepreneurship and professional training for imprisoned people and people who have just left prison (BRASIL, 2018). There are signs that imply the sedimentation of the notion of unification of efforts around public security, the outlines of cooperation among the federal entities show a movement that might optimizing the guidelines for elaborating public policies in this area. The funding for the Security Policy amounted to 84,7 billion in 2017, distributed among federal, state and municipal entities; the cost of each citizen was $R \$ 408,13$, corresponding to $1.3 \%$ of the GDP (FBSP, 2018)

The Violence Atlas 2018 (IPEA e FBSP, 2018) while presenting the increasing numbers concerning violence in Brazil, shows the urgent need of authorities implementing effective and committed actions in the three levels of government. It also foretells that the public security agenda must involve integrated and intersectional actions that include not only the Congress, the Justice System, the Public Prosecution and Public Defenders, but also the Church, businessmen and all civil society. According to the National Justice Council, in 2017, 2,7 million of new criminal court cases were registered in the Judiciary System (CNJ, 2018).

\section{Gender in Public Policies}

The inclusion of the gender issue in Brazilian public policies is still considered a new subject, gaining visibility only from the 80 's, in the redemocratization and social movements context. In this manner, aiming at integrated gender policies is still a distant aspiration, although some progress can be noticed. The demands, in this context, set the State as the main changevector through public policies (FARAH, 2004; SILVEIRA, 2004; SORJ, 2008; VASONE and SANTANA, 2015; FARAH, DINIZ, MARCONDES et al., 2018).

In the 80 's, Beauvoir (1980) summarizes the gender studies by affirming that individuals are born as male or female but become men and women, since being a man or a woman is not a destiny undertaken in society, but it is built through choices taken inside a civilization context. Bourdieu $(2012$, p. 17) points out that "[...] the division between sex seems to be natural". According to the author, it is present in an objective state in the things (in the house, for example, where all parts are "sexed"), in the entire social world and, in an embedded state, in the bodies and in the individual's habits, working as frameworks for perception, thought and action.

The concept of gender and its categories emphasize the social relation between genders and the power inequality that shows the subordinate position of women in society. This concerns the social construct of sexual identity, establishing a relation between behavior and personality opposed to the biological sex division (SOARES, 2004; SCAVONE, 2012; MUXí, 2014; MOTTA, 
2017). The inclusion of this discussion in the public agenda occurred in the end of the 70's. This discussion started because of women's mobilization seeking to overcome the inequalities (FARAH, 2004).

In order to include the gender issue in the public policies, a constant mobilization of feminist movements built along Brazilian history was necessary. Silveira (2004) highlights the importance of women social participation in spaces of political definition, competition for resources and mechanisms of social control around these policies, as well as, the possibility to access the spaces of decision. Supporting this position, Nascimento (2016) affirms that efficient gender public policies depend on the understanding of female needs and the active participation of women during the elaboration process.

Since the creation of the National Women Policies Secretary, in 2003, there has been progress in the building of public policies guided by transversality of gender. The National Women Policies Plan (PNPM), elaborated in 2004, worked as an instrument to enable this progress. Highlighting this milestone, Farah, Diniz, Marcondes et al. (2018) state that public policies that take gender into consideration started to occupy a central position after the creation of this entity, gaining more space in the government's agenda. In this scenario, the plan proposed a complex process to promote social participation and intersectorial actions aiming at reducing gender inequality. It is important to say that to change the spaces of oppression and the invisibility of women in the state structure, it is necessary adopting a public policy based on transversality and redefinition of concepts (BRASIL, 2013).

The gender discrimination is more evident towards imprisoned women. It becomes even more serious because almost no public police is developed in this area, making incarcerated women invisible and leading them to live new experiences that change substantially the way in which these women deal with some aspects of their lives (VIESENTEINER, 2013; CHESKYS, 2014).

\section{METHODOLOGY}

This is a qualitative piece of research, being a case study in a district, composed by eight municipalities, in the state of Minas Gerais. Because of the theme, the localization is not revealed. The research environments were the Regional Prison managed by the state power, through the State Social Defense Department, and the Association for Protection and Assistance for the Convicted (APAC). There were 682 inmates in the Regional Prison, 4 women and 678 men. In APAC, where 80 vacancies are available, there were 67 women, from which 28 were in pre-trial detention, this finding has been justified by the lack of other place where these women could stay.

The data collection happened through two different interview scripts, one targeted at the authorities related to the female prison system and other targeted at the imprisoned women. The script targeted at the managers was composed by 11 questions aiming at understanding how they perceive the gender differences during the execution of sentences, the policies built to fight gender inequality and the maternity. The scripted targeted at the women, composed by 14 questions, focused on the women's profiles according to the following aspects: age, profession and imprisonment time. Besides these aspects, 04 questions referred to their perception about gender influence on prison, 02 questions were about their understanding about public policies, 02 questions were directly related to maternity and 04 questions were about their prison experiences. In order to supplement the data, documental research was also used.

The data was collected between December 2017 and May 2018. After the presentation and explanation of the proposal to the interviewees, a Consent Form was made available, so all participants spontaneously agreed to take part in the research. The material was recorded and transcribed, generating 29 pages in total, an average of a page and a half per interviewee this is the analysis corpus. Each interview lasted around 30 to 40 minutes, depending on the interviewee's speech. There was no authorization for study to be carried out with the interviews in the Regional Prison, in this way, the study was focused on APAC, with 19 interviews, distributed among 02 managers and 17 imprisoned women.

The content analysis was seen as the ideal method to achieve the research goals, because it allows the discovery of what lies behind the manifested contents, moving beyond the appearances of what has been communicated (MINAYO, 2009). As it is a method, it uses systematic and objective procedures to describe the content of the messages, producing valid 
knowledge through the discovery of content and structures. From this perspective, the different stages of content analysis organize themselves in three chronological stages: the pre-analysis, the material exploration and the result processing. In this manner, data is made valid and relevant, arousing inferences and interpretation related to the proposed objectives (BARDIN, 2009; BARDIN, 2016).

Information was textually organized and structured based on the theory's premises determined by the content analysis. According to Bardin (2016) and Minayo (2009), the information collected, after several readings, were classified according to a categorization system defined by the pre-analysis, exploration, results treatment and interpretation. The categorization consisted of classifying the constitutive elements of a group by differentiation and subsequently regrouping them by analogy. The criterion was chosen according to textual categorization, in which the constitutive elements of a set were regrouped by common features they shared (BARDIN, 2016). Based on this analysis, four categories were built: imprisonment and gender; maternity and prison; public policies and prison experiences.

\section{RESULTS BASED ON THE IDENTIFIED CATEGORIES}

The socio-demographic profile of the imprisoned women was obtained. Among the 17 interviewees, all were born in the municipalities part of the district. The imprisoned women who were interviewed are around 34 years old; $75 \%$ have children, 3 children on average, most of them teenagers. Before prison, 06 interviewees were housewives, the others worked, mainly in informal jobs, such as craftswoman or caretaker. The two managers who were interviewed have different profiles, one is a member of the Judiciary Power (related to the Regional Prison) and the other one (related to APAC) held positions in the state and municipal Legislative Power.

Research has shown that, although the Regional Prison houses female inmates (4 women), it has no area built for women, taking into consideration their specificities and particularities. Thus, women who are in this place are obliged to live a temporary and improvised reality. Their accounts identify an unsuitable space, permeated by different types of violence. This finding was possible by analyzing the answers of 08 interviewees from APAC, who have already been imprisoned in the Regional Prison.

Regarding the physical structure, the APAC studied was one of the first ones built in Minas Gerais. According to the Court of Justice of Minas Gerais (TJMG), there are 11 APACs or women in the country, their methodology aims to promote the humanization of the penalty (MINAS GERAIS, 2018). The idea of humanization was presented by aspects reported during the interviews, such as: the inmates do not wear uniforms, they are responsible for the cooking, they take part in religious and physical activities, they have access to books, they have a special space destined to breastfeeding and they have the right of conjugal visit. Also as part of this methodology, they have access to a doctor and they take part in professional training programs, developed through handicraft activities (crochet, embroidery), cleaning and cooking activities as well. According to the interviewed managers, these actions strive for helping them in the rehabilitation and resocialization process.

\section{Category 1: imprisonment and gender}

The first category was the interface between imprisonment and issues related to gender. Although there has been some progress in legislation and in the female prison system, the imprisoned women remain in a position of invisibility characterized by the lack of respect for their physical, social and psychological needs. This category highlights the gender inequality in the prison context, as approached by Santa Rita (2006), when stating that the prison reflects the discrimination and the selectivity in the criminal justice system. The excerpts below show the analyzed category:

For women, it is worse. The prejudice against women is bigger. The society does not accept a mother being arrested. For them, we are bad people (E9).

There in the male APAC, they have more perks...they have more benefits. They get the hygiene kit. Here, we do not get shampoo, sanitary pads, soap. Our families have to buy everything (E12).

According to the interviewed managers, all condemned women in the district studied serve their sentences in the female APAC. The Regional Prison is destined for the ones who "break disciplinary rules", it is a punishment measure established by 
the Court of Criminal Enforcement. One of them even stated "APAC is purgatory, the Regional Prison is hell". This statement is reinforced by an incarcerated woman who was interviewed:

Here at APAC, we have dignity, respect. There, in the Regional Prison, when we asked something to the director, he would look at us and say: "don't bother me, get lost, I want to go out and drink my beer". They used to say that we deserved being beaten because we were naughty. There was pepper spray every day. Food there was awful, I arrived here looking like a skeleton. I didn't eat anything, food was horrible, it stank. At Christmas, they served rotten food to us. I don't want to go back there, no way (E3).

Another relation to the gender interface was the finding that 12 out of 17 interviewees have at least one male family member or male partner who are also in prison, a rate of 70,58\%. This data converges with the results obtained by Posada (2015) that, while studying a prison population, found out that the majority of them had at least a relative who had the imprisonment experience. Most of the women interviewed were arrested accused of drug dealing. One of the interviewed managers claims that as these women live in an environment in which crime - above all, drug dealing - is perpetrated by their sons, brothers and husbands, it becomes a standard practice.

Discussing the gender category shows the invisibility of imprisoned women and the lack of public policies that take the reality in the female prisons into consideration, as identified by Rampin (2011). According to Andrade (2011), the function associated to prison is the one of giving back to society good mothers and wives able to fulfill their social role.

\section{Category 2: maternity and prison}

According to a survey conducted by the National Justice Council (CNJ), by means of the National Registry of Pregnant and Breastfeeding Prisoners, there are 622 imprisoned women who are pregnant or breastfeeding - 373 are pregnant and 249 are breastfeeding. This data was collected until the last day of 2017. Most of these women are in prisons in the state of São Paulo, the state of Minas Gerais coming in second place (CNJ, 2018).

The main difficulty reported by the imprisoned women was the condition of the woman as a mother - out of 17 interviewees, only 4 had no children. All of them agreed that the maternity worsens the female position in prisons. While the research was conducted, there were no pregnant nor breastfeeding inmates, however, two interviewees got pregnant and had their babies while serving their sentence at APAC. Both reported the humiliation sensation and the solitude felt while living this experience. The suffering caused by the relation between maternity and prison made evident that being woman and mother makes it more difficult to face the deprivation of liberty - this category was also pointed out by Guedes (2006). The following excerpts depict this agonic situation:

Men are stronger, we are more sensitive, mothers suffer for their kids. I feel bad when I'm cooking and I remember him (the son), some food he like (E1).

It is more difficult for women because of the children. To see them crying is very sad (E2).

The Law number 13.257, from 2016, changed the Code of Criminal Procedure, establishing the replacement of pre-trial detention by house arrest for pregnant women or women with children aged 12 or younger (BRASIL, 2016). This possibility of alternative penalty could directly influence this category, however, in reality, the law has not been applied for most of the women. According to one of the managers, this modification in legislation changes drastically the history of female imprisonment, but "[...] it gives women a blank check to commit crimes, because they know they will not be arrested if they get pregnant and it is a child's right not having a criminal mother" (G2).

It is depicted here the understanding of maternity as merely a condition to conquer freedom, not taking into consideration its varied dimensions. On the other hand, according to the imprisoned women interviewed, having children functions as a motivation to change and not perpetrating more crimes, reinforcing the idea that the family bounds help the resocialization process for incarcerated women. Posada (2015) noticed that teenagers whose mothers were in prison had a risk 10,8 times bigger of having problems with justice in comparison to the teenagers whose fathers were in prison. The distancing undermines the bounds between mothers and children, jeopardizing their relationship and the possibility of taking care of them. 


\section{Category 3: public policies}

The structural axis of this category if formed by the theoretical discussion about public policies aiming to ensure actions related to resocialization are implemented. For this, actions that cover the female prison system and its peculiarities are needed. This was an essential category identified in this piece of research. This field sustains the idea that public policies are shaped in all stages by different social actors and institutions, taking into consideration that all different actors can establish relations (ALMEIDA and GOMES, 2018).

Aligned with Almeida and Gomes (2018), when thinking about the public policies process as something constituted by social actors, institutions, networks/subsystems, ideas/belies, contextual factors and events, it is possible to say that in the analyzed district, even though not properly, some programs aiming at resocialization and reinsertion in society are implemented. However, the various entities that think about public policies, in the research area, are mainly targeted at the male universe.

Some effective actions were identified. There is, at APAC, for instance, a room where the inmates can attend to classes and take the National High School Exam for people deprived of freedom and youth undergoing social-educational measure, ENEM PPL. The research found out that, by means of this process, in the male APAC, six inmates were approved in a federal university, while no women had this result. From this same perspective, the research found out that the project "Redemption via reading", recommended by the National Justice Council, only takes place in the male prison. Specifically, for the female prison, the Town Hall offers vacancies for street sweeping. All the interviewees complained about this situation, claiming that this scenario makes evident how men have perks women do not have.

Carrying this feeling and perception of exclusion from the government's agenda, the interviewees shared the idea that the resocialization process depends much more on their will than on state actions. A specific breakthrough, in the state of Minas Gerais, was the approval of the State Law number 22.864, from 2018, that established that $20 \%$ of the budget resources must be invested for the creation of new vacancies in prison unities managed by civil entities, as APAC. This conquer came as a result of the recognition of this institution ability to rehabilitate their inmates (MINAS GERAIS, 2018).

\section{Category 4: prison experiences}

Based on the theoretical position adopted - that is, the understanding that what is lived in prison has such intensity that can completely change individual existence - the category "experiences" was identified (BEZ BIROLO, 2010; VIESENTEINER, 2013). From this perspective, daily situations experienced by these women were framed, many of these experiences are permeated by different types of violence. When questioned about their adaptation to their new reality, the interviewees were unanimous to say how difficult it is to be a woman and to be in prison, since they have particularities that distinguish than from men.

For them, the experience in prison is responsible for great changes of subjective nature in their lives. It was noticed that, although the situations lived in prison are changing both for men and women, there are some peculiarities related to the female identity. Taking into consideration the fact that 08 out of 17 interviewees have already been kept in the Regional Prison, it was possible to identify in this category many types of violence experienced in this space.

There in the male APAC, they have more perks...they have more benefits. They get the hygiene kit. Here, we do not get shampoo, sanitary pads, soap. Our families have to buy everything (E12).

The conditions for women are worse, there's more disrespect. We lack good treatment and human appreciation. There in the Regional Prison, we had to "do our business" on the floor, there was no bathroom. Women suffer more, the difference is huge, we are morally destroyed and we feel scared (E1).

There (in the Regional Prison), we took shower together, ten women at once. We slept on top of one another (E3).

Conjugal visits are also a problem. You have to be in a civil partnership, you need witnesses. I have all this and they don't allow it (E9). 
We're humiliated all the time, they call us slut, tramp. There (in the Regional Prison), there should only be female prison guards, but the male ones go there all the time.

Men have more perks. Even the structure is different. I say that the male area is the castle and here it's the slave quarters (E16).

The women return to society is filled with the experiences lived by them while serving their sentences, and these experiences are perceived differently by men and women. In this category the role of the State is essential, through public policies that contemplate gender specificities. The disregard for the international treaties and the national legislation, as quoted by Almeida (2006), compromises the process of returning to society, because individuals who do not recognize themselves and who experienced the loss of family and personal bounds become stigmatized and find no reasons to keep on with their lives. The realities experienced by these women set the boundaries of prison as a legitimate space, where the consequences of being a space that generates stigmatized identities are challenged (SOUZA, COSTA and LOPES, 2019).

\section{FINAL CONSIDERATIONS}

This paper aimed to analyze how the gender difference, in the formulation of security public policies context, affects the female experiences in prison. Throughout collected data, four great categories were identified, among them, the category construct of "experiences" played a crucial role in this paper, highlighting the experiences responsible for generating invisibility and changing. Violence against women was regarded as a natural and rooted behavior; far from being punished, violence replicated in the relationships in prison leaves an indelible mark on women's lives (VIESENTEINER, 2013; MOTTA, 2017).

The category "maternity" is also related to "experiences" since it is the main difficult faced by the imprisoned women who are mothers. Empirically it was possible to notice their need of talking about the subject, giving vent to their feelings, showing emotional when remembering and longing for them. The law that ensures home arrest to pregnant women and women with children aged 12 or younger is still a challenge and it is not a legitimate right.

According to the theoretical frame, other category was analyzed and revealed the female prison system and the security public policies universes. Historically, penal legislation has not approached the issue of women committing crimes, strengthening the invisibility of female offenders. To analyze public policies related to the female prison system, as well as the reality experienced by these women, brings about the need of state actions taken by a different perspective, including the gender issue in the formulation of public policies. There is still a huge challenge to be faced, the one concerning changing the rules that regulate women's rights protection inside prisons. A thorough investigation about the structural and conjectural dimensions implied in the current scenario of women criminalization and imprisonment is needed (GERMANO, MONTEIRO and LIBERATO, 2018).

The identified categories showed the need of a turning point regarding female imprisonment. The disregard for the peculiarities of this universe reinforces a stigmatized and inefficient view that, in most cases, prevents imprisoned women to serve their sentences enjoying their fundamental rights. The prison system managers who were interviewed argued that it is difficult to "deal with women" and that they have many problems of coexistence. In this respect, many institutions tend to work on avoiding and repressing a behavior assigned exclusively to the female gender.

This paper does not intend to find ultimate solutions for the problems present in the female prison system, it aims to proceed with the debate. The context surrounding the theme needs to be historically and critically approached through more empirical immersions. Among the constraints faced by this study, the lack of authorization to interview the women in the Regional Prison must be highlighted. The analysis of this space was possible because of the number of interviewees that served part of their sentences there. The broadening of this field of investigation must undergo many designations and rearrangements. In this manner, the final thought is based on the deconstruction of a unique identity. If the female prison universe was identified as a space that leads to women invisibility, what would be the reality of new identities built among a range of new identities and social subjectivities? 


\section{REFERENCES}

ADORNO, S. Crime e violência na sociedade brasileira contemporânea. Jornal de Psicologia-PSI, n. 132, Apr./June, p. 7-8, 2002.

ALMEIDA, J. L. Os limites e as potencialidades de uma ação profissional emancipatória no sistema prisional brasileiro. 2006. 138f. Master Thesis (Master Degree in Social Service) - Universidade Federal de Santa Catarina, Florianópolis, 2006.

ALMEIDA, L.; GOMES, R. C. Processo das políticas públicas: revisão de literatura, reflexões teóricas e apontamentos para futuras pesquisas. Cadernos EBAPE.BR, v. 16, n.3, p. 444-455, 2018.

ANDRADE, B. S. A. B. Entre as leis da Ciência, do Estado e de Deus: O surgimento dos presídios no Brasil. 2011. 317 f. Master Thesis (Master Degree in Social Anthropology) - Universidade de São Paulo, São Paulo, 2011.

ARTUR, A. T. "Presídio de Mulheres": as origens e os primeiros anos de estabelecimento. São Paulo, 1930-1950. In: SIMPÓSIO NACIONAL DE HISTÓRIA, 25., Fortaleza, 2009. Anais... Fortaleza: ANPUH, 2009. Available at: <https://anpuh.org.br/uploads/anais-simposios/ pdf/2019-01/1548772192_1635d32f7239cd3bcf643523baabdd02. pdf>. Accessed on: Oct. 17, 2019.

BARDIN, L. Análise de Conteúdo. 4 ed. Lisboa: Edições 70, 2009.

BARDIN, L. Análise de Conteúdo. São Paulo: Edições 70, 2016.

BEAUVOIR, S. O segundo sexo. 3.ed. Rio de Janeiro: Nova Fronteira, 1980.

BEZ BIROLO, I. V. Puerpério em ambiente prisional: vivência de mulheres. 2010. 125f. Master Thesis (Master Degree in Nursing) Universidade Federal de Santa Catarina, Centro de Ciências da Saúde, Programa de Pós-Graduação em Enfermagem, Florianópolis, 2010.

BORGES, Paulo César Corrêa. Direito penal democrático. São Paulo: Lemos e Cruz, 2005.

BOURDIEU, P. A dominação masculina. 11. ed. Rio de Janeiro: Bertand Brasil, 2012.

BRASIL. Constituição (1988). Constituição da República Federativa do Brasil: promulgada em 5 de outubro de 1988. 4. ed. São Paulo: Saraiva, 1990.

BRASIL. Ministério Público do Distrito Federal e Territórios. Plano Nacional de Segurança Pública. Brasília, DF: Governo Federal, 2000. Available at: <http://www.mpdft.mp.br/portal/pdf/unidades/ procuradoria_geral/nicceap/legis_armas/Legislacao_completa/

Plano_Nacional_de_Seguranca_Publica_2000_2002.pdf $>$. Accessed on: Oct. 18, 2019.

BRASIL. Presidência da República. Plano Nacional de Políticas para as Mulheres. Brasília, DF: Secretaria Especial de Políticas para as Mulheres, 2013.

BRASIL. Departamento Penitenciário Nacional. Levantamento Nacional de Informações Penitenciárias - Infopen Mulheres, 2. ed. Brasília, DF: Ministério da Justiça e da Segurança Pública, 2017a. Available at: <http://depen.gov.br/DEPEN/depen/sisdepen/infopen-mulheres/ infopenmulheres_arte_07-03-18.pdf>. Accessed on: Oct. 18, 2019.

BRASIL. Política Nacional de Segurança Pública e Defesa Social. Plano Nacional de Segurança Pública e Defesa Social 2018-2028. Brasília, DF: Ministério da Justiça e Segurança Pública, 2017b.
BRASIL. Decreto no 9.450, de 24 de julho de 2018. Dispõe sobre o procedimento de contratação de mão de obra formada por pessoas presas ou egressas do sistema prisional. Portaria Interministerial № 3, de 11 de setembro de 2018.

BRASIL. Lei no 13.257, de 08 de março de 2016. 2016. Available at: <http://www.planalto.gov.br/CCIVil_03/_Ato2015-2018/2016/Lei/ L13257.htm> Accessed on: Apr. 04, 2018.

BREUS, T. L. Políticas Públicas no Estado Constitucional: a problemática da concretização dos direitos fundamentais sociais pela Administração Pública Brasileira Contemporânea. 2006. 244 f. Master Thesis (Master Degree in State Law) - Universidade Federal do Paraná, Curitiba, 2006.

CARVALHO, V. A.; SILVA, M. R. F. Política de segurança pública no Brasil: avanços, limites e desafios. Revista Katálysis v. 14, n. 1, p. 59-67, jan./jun. 2011.

CHESKYS, D. Mulheres invisíveis: uma análise da influência dos estereótipos de gênero na vida de mulheres encarceradas. 2014. 134 f. Master Thesis (Master Degree in Law) - Pontifícia Universidade Católica do Rio de Janeiro, Rio de Janeiro, 2014.

CONSELHO NACIONAL DE JUSTIÇA - CNJ. Brasil tem 622 grávidas ou lactantes em presídios. 2018. Available at: <http://www.cnj.jus. br/noticias/cnj/86062-brasil-tem-622-gravidas-ou-lactantes-empresidios>. Accessed on: Oct. 18, 2019.

CORTES, S. M. V.; LIMA, L. L. A contribuição da sociologia para a análise de políticas públicas. Lua Nova, v. 87, p. 33-62, 2012.

FARAH, M. F. S. Gênero e políticas públicas. Estudos feministas, v. 12, n. 1, p. 47-71, Jan./Apr. 2004.

FARAH, M. F. S. et al. Gênero e política pública: panorama da produção acadêmica no Brasil (1983-2015). Cadernos EBAPE.BR, Rio de Janeiro, v. 16, n. 3, p. 428-443, 2018.

FÓRUM BRASILEIRO DE SEGURANÇA PÚBLICA - FBSP. Anuário Brasileiro de Segurança Pública. 11. ed. São Paulo: Fórum Brasileiro de Segurança Pública, 2018.

FILOCRE, D'Aquino. Classificações de políticas de segurança pública. Revista Brasileira de Segurança Pública, ano 3, ed. 5, p. 146-158,Aug./ Sept. 2009.

FONSECA, F. A trama conflituosa das políticas públicas: Lógicas e projetos em disputa. Cadernos EBAPE.BR, v. 14, n. esp., p. 406417, 2016.

FRANÇA, M. H. O. Criminalidade e prisão feminina: uma análise da questão de gênero. Revista Ártemis, v. 18, n. 1, p. 212-227, 2014.

FREIRE, M. D. Paradigmas de segurança no Brasil: da ditadura aos nossos dias. Aurora, ano 3, n. 5, p. 49-58, 2009.

GERMANO, I. M. P.; MONTEIRO, R. A. F. G.; LIBERATO, M.T. C. Criminologia Crítica, Feminismo e Interseccionalidade na Abordagem do Aumento do Encarceramento Feminino. Psicologia: Ciência e Profissão, Brasília, v. 38, n. esp., p. 27-43, 2018. Available at: $<$ http://www.scielo.br/scielo.php?script=sci_arttext\&pid=S141498932018000600027\&lng=pt\&nrm=iso>. Accessed on: Oct. 18, 2019. 
GUEDES, M. A. Intervenções psicossociais no sistema carcerário feminino. Revista Psicologia: Ciência e Profissão, v. 26, n. 4, p. 558-569, 2006.

INSTITUTO DE PESQUISA ECONÔMICA APLICADA - IPEA; FÓRUM BRASILEIRO DE SEGURANÇA PÚBLICA - FBSP. Atlas da Violência 2018. 2018. Available at: <http://www.ipea.gov.br/portal/index. php?option=com_content $\&$ view $=$ article $\& i d=33410 \&$ Itemid $=432>$. Accessed on: May 20, 2018.

LIMA, G. M. R. Continuidade de políticas públicas: a constitucionalização importa? 2011. 73 f. Master Thesis (Master Degree in Public Administration and Government) - Fundação Getúlio Vargas, São Paulo, 2011.

LIMA, R. S.; BUENO, S.; MINGARDI, G. Estados, polícia e segurança pública no Brasil. Revista Direito GV, São Paulo, v. 12, n.1, p. 49-85, Jan./Apr. 2016.

MATOS, M. Teorias de gênero ou teorias e gênero? Se e como os estudos de gênero e feministas se transformaram em um campo novo para as ciências. Estudos Feministas, v. 16, n. 2, p. 333-357, 2008.

MINAS GERAIS. Tribunal de Justiça do Estado de Minas Gerais. 2018. Available at: <http://www.tjmg.jus.br/portal-tjmg/noticias/ apac-feminina-de-sao-joao-del-rei-e-inaugurada-oficialmente.htm\#. XbMM4-hKiUk>. Accessed on: Dec. 11, 2018.

MINAYO, M. C. S. (Org.) Pesquisa social: teoria, método e criatividade. 21. ed. Petrópolis: Vozes, 2009.

MOTTA, M. C. C. Invisibilidades e persistências: políticas públicas de combate à Violência contra as Mulheres (Brasil e Argentina). 2017. 327f. Doctoral Dissertation (Doctor Degree in Social Sciences) - Universidade de Brasília, Brasília, 2017.

MUXÍ, Z. Mujeres en arquitectura y urbanismo. Summa+, Buenos Aires, n. 136, p. 144-147, jun., 2014.

NASCIMENTO, J. X. Políticas Públicas e Desigualdade de Gênero na Sociedade Brasileira: Considerações Sobre os Campos do Trabalho, da Política e da Ciência. Mediações, v. 21, n. 1, p. 317-337, July/Dec. 2016.

POSADA, R. A. U. Questões associadas ao encarceramento parental: uma análise das características da população de pais e mães encarcerados e da situação de seus filhos em Minas Gerais, 2014. 2015. 177 f. Master Thesis (Master Degree in Demography) Universidade Federal de Minas Gerais, Belo Horizonte, 2015.

RAMPIN, T. T. D. Mulher e sistema penitenciário: a institucionalização da violência de gênero. In: BORGES, P. C. C. (Org.). Sistema Penal e Gênero: tópicos para a emancipação feminina. São Paulo: Cultura Acadêmica, 2011.

SANTA RITA, R. P. Mães e crianças atrás das grades: em questão o princípio da dignidade da pessoa humana. 2006. 180 f. Master Thesis (Master Degree in Social Policy) - Universidade de Brasília, Brasília, 2006.

SARAVIA, E. Introdução à teoria da política pública. In: SARAVIA, E.; FERRAREZI, E. (Org.). Políticas públicas. Brasília, DF: ENAP, 2006. v. 1. p. 21-42.
SCAVONE, L. Gênero, feminismo e políticas sociais. In: SOUZA, L. A. F; MAGALHÃES, B. R.; SABATINE, T. T. (Org.). Desafios à Segurança Pública: controle social, democracia e gênero. São Paulo: Cultura Acadêmica, 2012. 228p.

SCHABBACH, L. M. A agenda da segurança pública no Brasil e suas (novas) políticas. In: MADEIRA, L. M. (Org.). Avaliação de Políticas Públicas. Porto Alegre: UFRGS, 2014. 254p.

SILVA, J. A. Comentário contextual à Constituição. São Paulo: Malheiros, 2009.

SILVEIRA, M. L. Políticas públicas de gênero: impasses e desafios para fortalecer a agenda política na perspectiva da igualdade. In: GODINHO, T.; SILVEIRA, M. L. (Org.). Políticas públicas e igualdade de gênero. São Paulo: Coordenadoria Especial da Mulher, 2004.

SOARES, V. Políticas públicas para igualdade: papel do Estado e diretrizes. In: GODINHO, T.; SILVEIRA, M. L. (Org.). Políticas públicas e igualdade de gênero. São Paulo: Coordenadoria Especial da Mulher, 2004.

SORJ, B. A Revista Estudos Feministas e as políticas públicas: qual relação? Estudos Feministas, v. 16, n. 1, p. 129-130, 2008.

SOUZA, C. Políticas públicas: questões temáticas e de pesquisa. Caderno CRH, n. 39, p. 11-24, July/Dec. Salvador, 2003.

SOUZA, C. Políticas Públicas: uma revisão da literatura. Sociologias, Porto Alegre, v. 8, n. 16, p. 20-45, July/Dec. 2006.

SOUZA, E. M.; COSTA, A. M.; LOPES, B. C. Ressocialização, trabalho e resistência: mulheres encarceradas e a produção do sujeito delinquente. Cadernos EBAPE.BR, Rio de Janeiro, v. 17, n. 2, p. 362-374, 2019.

SOUZA, L. A. F. et al. Políticas locais de segurança pública. In: SOUZA, L.A.F. (Org.). Políticas Públicas de Segurança no Estado de São Paulo: situações e perspectivas a partir das pesquisas do Observatório de Segurança Pública da UNESP. São Paulo: Editora UNESP, 2009.

UZIEL. A. P. SCISLESKI, A. C. C. Sistema Prisional e Segurança Pública: Inquietações e Contribuições da/à Psicologia. Psicologia: Ciência e Profissão v. 38, n. esp., p. 3-9, 2018.

VASONE, N. B.; SANTANA, I. J. Mulheres e Prisão; Gestação e Liberdade. In: SCIENCULT, 11., Parnaíba, 2015. Cadernos de programação e resumos. Organização: Maria Silvia Rosa Santana. Paranaíba, MS: UEMS, 2015. v. 11

VIESENTEINER, J. L. O conceito de vivência (Erlebnis) em Nietzsche: Gênese, significado e recepção. Kriterion, Belo Horizonte, n. 127, p. 141-155, June 2013.

ZACCHI, J. M. Prevenção da violência: avanços e desafios na ordem do dia. In: ILANUD. Das Políticas de Segurança Pública às Políticas Públicas de Segurança. São Paulo: ILANUD, 2002. p. 31-42. 
Bruna Rios Martins Santos

ORCID: https://orcid.org/0000-0002-3987-3613

Master's in Public Administration from the Federal University of São João del Rei (UFSJ); Nurse at the Federal University of São João del Rei (UFSJ), São João del Rei- MG, Brazil. E-mail: brunariosm@ufsj.edu.br

Vânia Aparecida Rezende ORCID: https://orcid.org/0000-0002-9879-4552

Ph.D. in Administration from the Graduate Program in Administration at the Federal University of Lavras (UFLA); Associate Professor at the Federal University of São João del Rei (UFSJ), São João del Rei-MG, Brazil. E-mail: vaniarezende@ufsj.edu.br 